\title{
Nitrogen-limited growth in the coral reef chlorophyte Dictyosphaeria cavernosa, and the effect of exposure to sediment-derived nitrogen on growth
}

\author{
Scott T. Larned*, John Stimson \\ Department of Zoology, University of Hawai'i at Manoa, Honolulu, Hawai'i 96822-2279, USA
}

\begin{abstract}
The macroalga Dictyosphaeria cavernosa grows profusely on the reef slopes of Kane'ohe Bay, Hawai'i (USA), despite low inorganic nutrient concentrations in the water column. When cultured outdoors in laboratory containers supplied with flowing seawater from the Kane ohe Bay water column. the growth of thalli was limited by inorganic nitrogen availability, even though water motion in the containers was greater than in the field. Approximately $1 \mu \mathrm{M}$ DIN (dissolved inorganic nitrogen) was required to sustain growth during 10 to $12 \mathrm{~d}$ experimental runs, but Kane'ohe Bay water column DIN concentrations are usually less than $0.5 \mu \mathrm{M}$, too low to sustain growth in the laboratory. The unusual morphology of $D$. cavernosa thalli suggested a possible mechanisn for the acquisition of sufficient DIN for sustained growth in the field. Thalli are anchored to living or dead coral colonies, and form thick canopies spanning the substratum. The enclosed spaces or chambers beneath thalli isolate volumes of water over sediment patches, and prevent sediment-derived nutrients from mixing into the overlying water column. Ammonium concentrations are nearly twice as high, and nitrate+nitrite concentrations are 10 times higher within $D$. cavernosa chambers than in the adjacent water column. The DINenriched water within chambers exceeds the minimum DIN requirement of the alga for sustained growth. Results from a field experiment indicated that growth rates of $D$. cavernosa thalli exposed to both DIN released from sediments and DIN from the water column were significantly higher than growth rates of thalli exposed only to DIN from the water column. Experimental D. cavernosa thalli utilized ammonium and, to a lesser degree, nitrate for growth, but organic nitrogen (urea) enrichment had no effect on growth. Results from tissue nutrient analyses suggested that the nitrogen storage capacity of $D$. cavernosa is very low; the alga appears to require a continual supply of DIN, at a concentration greater than that of the water column, to sustain growth.
\end{abstract}

KEY WORDS: Coral reef Dictyosphaeria cavernosa - Growth - Macroalgae - Nitrogen limitation Sediment - Tissue nitrogen

\section{INTRODUCTION}

Recent studies of coral reef communities subject to anthropogenic nutrient enrichment have documented shifts from coral to macroalgal domination of productivity and cover (Littler et al. 1993, Naim 1993). On some reef slopes, however, high macroalgal productivity and cover is sustained despite low inorganic

\footnotetext{
•E-mail: slarned@zoogate.zoo.hawaii.edu
}

nutrient concentrations in the water column (Coles 1988, Lapointe et al. 1993, Stimson et al. 1996). In these cases, localized sources of nutrient input may provide a substantial fraction of the nutrient requirements of macroalgae. Potential sources of localized enrichment include excretion by macrofauna (Meyer \& Schultz 1985, Williams \& Carpenter 1988), stream runoff (Marsh 1977), ground water discharge (D'Elia et al. 1981, Lewis 1987), nitrogen fixing bacteria (Capone et al. 1992) and remineralization of organic matter in cavities and sediment patches (Andrews \& Müller 1983, 
Williams et al. 1985, Hansen et al. 1987, Johnstone et al. 1989, Capone et al. 1992, Boucher et al. 1994). If rates of nutrient release from these sources are high relative to rates of dilution into the water column, primary producers near the sources may be exposed to higher nutrient concentrations than ambient, and productivity may be enhanced. Tropical turf algae and seagrasses have been shown to benefit from localized enrichment due to macrofaunal excretion (Williams \& Carpenter 1988, Powell et al. 1989). Some rhizophytic macroalgae may acquire nutrients directly from nutrient-rich sediment porewater via rhizoid holdfasts (Williams 1984, Littler et al. 1988, McGlathery et al. 1992) Most coral reef macroalgae do not possess rhizoids, however, and do not have direct access to sediment porewater. Acquisition of sediment-derived nutrients from the poorly-mixed water near sediment surfaces by macroalgae has been suggested (Entsch et al. 1983, Stimson et al. 1996), but has not been demonstrated.

Stimson et al. (1996) showed that growth (increase in wet weight per day) of the coral reef macroalga Dictyosphaeria cavernosa (Forskăl) Borgesen is nitrogenlimited in Kane'ohe Bay, O'ahu, Hawai'i (USA). Although $D$. cavernosa is both abundant (up to $30 \%$ cover on shallow patch and fringing reef slopes) and persistent (for at least 3 decades) in Kane'ohe Bay, water column dissolved inorganic nitrogen (DIN) levels appear to be too low to support sustained thallus growth. Experimental D. cavernosa thalli cultured in flowing, unenriched or phosphate-enriched seawater from the Kane'ohe Bay water column did not sustain net growth, while thalli cultured in ammoniumenriched seawater sustained growth throughout experimental runs. Stimson et al. (1996) suggested that D. cavernosa can grow and persist in Kane'ohe Bay by utilizing DIN that is released from sediments and benthic organisms, and trapped beneath $D$. cavernosa thalli. Thalli growing on reef slopes are anchored to live corals and limestone rubble, forming canopies up to $1 \mathrm{~m}$ across with enclosed volumes of water beneath them. These chambers contain the skeletal remains of overgrown corals, accumulations of fine sediment, and invertebrates which inhabit the thallus, sediment and coral skeletons. Ammonium and nitrate concentrations within these chambers are significantly higher than in the water column adjacent to thalli (Stimson et al. 1996, present study).

In the present study, Dictyosphaeria cavernosa was grown in culture at a range of DIN concentrations to test the hypothesis that DIN concentrations within chambers are sufficient to sustain growth. Because both nitrate and ammonium concentrations are higher within chambers than in the adjacent water column, a factorial culture experiment was carried out using these nitrogen sources separately and in combination. Dissolved organic nitrogen (DON) concentrations are higher than DIN concentrations both in the Kane'ohe Bay water column and within $D$. cavernosa chambers (Smith et al. 1981, present study), therefore, an additional factorial experiment was carried out to determine whether DON (as urea) enrichment enhances growth in $D$. cavernosa. To compare in situ growth rates of $D$. cavernosa thalli exposed to and isolated from sediments, a field experiment was carried out on a patch reef in southern Kane'ohe Bay.

\section{MATERIALS AND METHODS}

Measurements of dissolved nutrient concentrations. Water samples were collected for nutrient analysis from within Dictyosphaeria cavernosa chambers on the slopes of patch reefs in southern Kane'ohe Bay, and from the water column about $1 \mathrm{~m}$ from the chambers. Water samples from $D$. cavernosa chambers were collected with acid-washed $(10 \% \mathrm{HCl}) 150 \mathrm{ml}$ syringes with $15 \mathrm{~cm}$ Pasteur pipettes attached to the tips. The pipettes were pushed through a thallus into the underlying chamber, and a small volume of water was discharged from the syringe to clear the pipette before the chamber sample was withdrawn. Samples from the adjacent water column were collected with identical syringes and pipettes. Paired D. cavernosa chamber and water column samples were collected at irregular intervals from July 1993 to July 1995. Additional water samples were collected 2 to 4 times a month for $23 \mathrm{mo}$ at a fixed site at $2 \mathrm{~m}$ depth on the windward reef slope of Moku o Lo'e (Coconut Island), the site of the Hawai'i Institute of Marine Biology in southern Kane'ohe Bay. All water samples were discharged through glass fiber filters (Whatman GF/F) into acid-washed Nalgene bottles and frozen until analysis. Measurements of ammonium, nitrate+nitrite, phosphate, total dissolved nitrogen and total dissolved phosphorus concentrations were made at Analytical Services, University of Hawaii, using a Technicon Autoanalyzer II. Organic nitrogen and organic phosphorus concentrations were calculated by subtracting ammonium and nitrate+nitrite from total dissolved nitrogen concentrations, and phosphate from total dissolved phosphorus concentrations.

Dictyosphaeria cavernosa preparation and culture. Laboratory experiments were carried out at the Hawai'i Institute of Marine Biology. Small (1 to $3 \mathrm{~g}$ wet wt) $D$. cavernosa thalli were collected for laboratory experiments on the reef slopes (2 to $3 \mathrm{~m}$ depth) of 2 patch reefs near Moku o Lo'e. New collections of thalli were made for each experimental run. Within $1 \mathrm{~h}$ of collection, thalli were placed in a flat $(3 \mathrm{~cm}$ high) vinylcoated metal. cage to exclude grazers and prevent self- 
shading, and were then preconditioned for 3 to $4 \mathrm{~d}$ on the Moku o Lo'e reef slope at $2 \mathrm{~m}$ depth. Results from a preliminary study indicated that the variance of thallus growth rates decreased significantly after $3 \mathrm{~d}$ of pre. conditioning. Following preconditioning, thalli were cleaned, blotted dry and weighed, then assigned at random to experimental treatments. To determine whether a non-linear relationship exists between thallus weight and growth, the growth $\left(\Delta \mathrm{g} \mathrm{d}^{-1}\right)$ of 32 thalli was calculated after preconditioning and before nutrient treatments began, and the growth rates were regressed on wet weight. Growth of these thalli showed a positive linear relationship to wet weight and a $Y$-intercept which was not significantly different from zero. Thereafter, growth rates of experimental thalli were calculated as specific growth in wet weight $\left(\mathrm{g} \mathrm{g}^{-1} \mathrm{~d}^{-1}\right)$. A wet weight-dry weight regression was also calculated for 55 D. cavernosa thalli collected in July 1994. These thalli were preconditioned as described above, blotted dry and weighed, then dried to constant weight at $65^{\circ} \mathrm{C}$. The relationship between wet and dry weights was: dry wt $=0.069$ (wet wt) $-0.003, R^{2}=0.92$, $\mathrm{p}<0.001$

Experimental thalli were grown in an outdoor culture system in opaque white 3 l containers, each housing 3 thalli. Containers were supplied with flowing seawater and deration. Seawater pumped from the Kane'ohe Bay water column (approximately $2 \mathrm{~m}$ depth) was coarsely filtered $(100 \mu \mathrm{m})$ to reduce sediment accumulation in water lines and containers. Filtered seawater was then pumped to a headbox to maintain constant flow rates of $350 \mathrm{ml} \mathrm{min}^{-1}$ containe $^{-1}$. Containers were shaded to $25-40 \%$ of full sun with neutral density shade cloth to compensate for the shallowness of the containers. Resulting irradiance levels corresponded to reef slope depths of approximately 2 to $4 \mathrm{~m}$, based on irradiance profiles made between May and December 1994 All irradiance (PAR: photosynthetically active radiation) measurements were made with a submersible Biospherical QSI-140 meter and a $4 \pi$ sensor. Experimental runs lasted 10 to $12 \mathrm{~d}$ and thalli were cleaned and weighed at 1 to $2 \mathrm{~d}$ intervals. The durations of runs were determined a priori, based on results from pilot studies.

Nutrient solutions were continuously supplied to thalli assigned to enrichment treatments. A peristaltic pump was used to pump nutrient concentrates from carboys to 41 nutrient-seawater mixing chambers located downstream from the headbox and upstream from the culture containers. Water flowing from the mixing chambers entered PVC manifolds which in turn supplied the culture containers through Tygon water lines. Four water lines carrying either nutrientenriched or ambient (unenriched) seawater entered each culture container Different nutrient levels were supplied to the culture containers assigned them by varying the ratio of nutrient-enriched to ambient water lines. Fluorescein dye was used to confirm that complete mixing had taken place before enriched seawater reached the containers. Aeration was used to mix the ambient and nutrient-enriched seawater within containers. Ammonium, nitrate, and urea solutions were prepared with $100 \mu \mathrm{m}$-filtered Kane'ohe Bay seawater and reagent grade $\mathrm{NH}_{4} \mathrm{Cl}, \mathrm{NaNO}_{3}$ and urea, respectively. Containers and waterlines were cleaned with bleach every 3 or $4 \mathrm{~d}$. Filters were cleaned every 1 or $2 \mathrm{~d}$.

Flow rates at field sites and in laboratory containers were measured by the dissolution of plaster cubes or 'clod cards' (see Jokiel \& Morrissey 1993 and Thompson \& Glenn 1994 for evaluations of clod cards for flow characterization). Clod cards were made from Grade 1 pottery plaster $\left(\mathrm{CaSO}_{4}\right.$ hemihydrate) and tap water (6 parts dry plaster to 5 parts water), using ice cube trays for molds. After drying to constant weight in a dehumidified laboratory, the plaster cubes were weighed, the bottoms sanded to adjust the starting weights to $24-27 \mathrm{~g}$, and the clods glued with contact cement to vinyl $50 \mathrm{~cm}^{2}$ cards.

In the field, flow rates were measured at the the surface of large Dictyosphaeria cavernosa thalli at sites on the windward and leeward sides of Moku o Lo'e, and beneath the same thalli in naturally occurring chambers. Flow rates were also measured at a field experiment site; in this case, clod cards were attached to bricks which were then placed on sediment patches used for the experiment. In the laboratory, clod cards were placed in the $3 \mathrm{l}$ culture containers, and exposed to the same seawater flow rate ( $350 \mathrm{ml} \mathrm{min}{ }^{-1}$ ) and aeration used during culture experiments.

After exposure in the field ( 16 to $25 \mathrm{~h}$ ) and the laboratory (10 to $11 \mathrm{~h}$ ), the clod cards were returned to the lab, rinsed in freshwater to remove salt, dried for constant weight and reweighed. To calibrate the clod cards, the dissolution rates of additional clod cards from the same batch were measured at fixed flow rates in a $24 \mathrm{~m}$ long by $0.4 \mathrm{~m}$ wide by $20 \mathrm{~cm}$ deep oval flume (Atkinson \& Bilger 1992). Plaster dissolution rates were measured at 5 velocities from 0 to $20 \mathrm{~cm} \mathrm{~s}^{-1}$, using 6 clod cards per velocity. Regressions of dissolution rates on flow rate in the flume, and inverse predictions from those regressions (Sokal \& Rohlf 1981), were used to predict relative flow rates in the field and in laboratory containers. Estimated field and laboratory flow rates are 'relative' because the clod cards relate multidirectional flow in the field to unidirectional flow in the flume. Estimated field and laboratory flow rates always fell within the range used for calibration. The estimated flow rate in the laboratory containers was $9.51 \pm$ $3.00 \mathrm{~cm} \mathrm{~s}^{-1}$ (mean \pm 1 standard deviation, $\left.\mathrm{n}=24\right)$. 
Lab Expt 1: Subsistence DIN level. To determine the subsistence DIN level (the external DIN concentration required to sustain positive growth) for Dictyosphaeria cavernosa at the estimated laboratory flow rate of $9.5 \mathrm{~cm} \mathrm{~s}^{-1}$, an ammonium enrichment experiment was carried out. Ammonium concentrations were: ambient (amb), $0.125 \mu \mathrm{M}+\mathrm{amb}, 0.25 \mu \mathrm{M}+\mathrm{amb}, 0.375 \mu \mathrm{M}+\mathrm{amb}$ and $0.5 \mu \mathrm{M}+\mathrm{amb}$. Ambient DIN concentrations during the experiment were $0.38 \pm 0.13 \mu \mathrm{M}$ ammonium and $0.41 \pm 0.17 \mu \mathrm{M}$ nitrate+nitrite (means \pm 1 standard deviation, $\mathrm{n}=6$ ). Treatments were replicated twice per run, and three $10 \mathrm{~d}$ runs were performed from June 1994 to April 1995.

Lab Expt 2: Saturating DIN level. A range of ammonium concentrations were continuously provided to Dictyosphaeria cavernosa thalli to determine the external DIN concentration at which growth is saturated at the laboratory flow rate of $9.5 \mathrm{~cm} \mathrm{~s}^{-1}$. The methods used in this experiment were identical to those used in Expt 1, except that ammonium enrichment levels were increased. Ammonium concentrations were: ambient, $1.0 \mu \mathrm{M}+a \mathrm{mb}, 2.5 \mu \mathrm{M}+\mathrm{amb}, 3.6 \mu \mathrm{M}+a \mathrm{mb}, 4.5 \mu \mathrm{M}+\mathrm{amb}$, $8.0 \mu \mathrm{M}+a m b, \quad 16.0 \mu \mathrm{M}+\mathrm{amb}, \quad 24.0 \mu \mathrm{M}+\mathrm{amb}$ and $32.0 \mu \mathrm{M}+\mathrm{amb}$. Ambient DIN concentrations during the experiment were $0.54 \pm 0.18 \mu \mathrm{M}$ ammonium and $0.54 \pm$ $0.37 \mu \mathrm{M}$ nitrate+nitrite (means \pm 1 standard deviation, $\mathrm{n}=4)$. Treatments were replicated twice per run, and three $12 \mathrm{~d}$ runs were performed from August 1994 to February 1995.

Tissue nitrogen and carbon analysis. Tissue nitrogen and carbon levels and N.C atomic ratios in experimental. Dictyosphaeria cavernosa thalli from Expts 1 and 2 were measured to assess the effects of nitrogen enrichment on nitrogen storage, and to determine subsistence and critical tissue nitrogen levels. Subsistence and critical tissue nutrient levels are defined as the concentration of limiting nutrient in tissues at which growth is sustained and maximum growth rates are achieved, respectively (Raven 1984, Rosenberg et al. 1984). At the end of the first 2 runs of Expts 1 and 2, the thalli were washed twice with deionized water and dried to constant weight at 60 to $65^{\circ} \mathrm{C}$. Dried thalli were then frozen in ashed vials, lyophilized for $4 \mathrm{~h}$, and ground in a mortar to yield a fine homogenous powder. The thalli from each experimental container were pooled to yield about $100 \mathrm{mg}$ dried tissue. Aliquots of tissue (16 to $20 \mathrm{mg}$ ) were analyzed using a PerkinElmer $2400 \mathrm{CHN}$ Analyzer.

Lab Expt 3: Ammonium-vs nitrate-enhanced growth. Because both ammonium and nitrate are available at elevated levels below large Dictyosphaeria cavernosa thalli in the field, a factorial nutrient experiment was carried out to determine individual and combined effects of ammonium and nitrate enrichment on $D$. cavernosa growth. Thalli were provided with one of 3 levels of ammonium (ambient, $0.5 \mu \mathrm{M}+\mathrm{amb}, 2 \mu \mathrm{M}+\mathrm{amb}$ ) and 1 of 3 levels of nitrate (ambient, $0.5 \mu \mathrm{M}+a \mathrm{mb}$, $2 \mu \mathrm{M}+\mathrm{amb}$ ) during 5 replicate $11 \mathrm{~d}$ runs from January 1994 to April 1995. Ambient DIN concentrations during the experimental runs were $0.54 \pm 0.24 \mu \mathrm{M}$ ammonium and $0.47 \pm 0.28 \mu \mathrm{M}$ nitrate + nitrite (means \pm 1 standard deviation, $\mathrm{n}=8$ ).

Lab Expt 4: Ammonium- vs urea-enhanced growth. To determine whether DON enrichment enhances Dictyosphaeria cavernosa growth, and whether DON enrichment effects DIN utilization, a factorial enrichment experiment was carried out using continuously supplied ammonium and urea. Thalli were provided with 1 of 3 levels of ammonium (ambient, $1 \mu \mathrm{M}+\mathrm{amb}, 2 \mu \mathrm{M}+\mathrm{amb})$ and one of 3 levels of urea (ambient, $2 \mu \mathrm{M}+a m b, 4 \mu \mathrm{M}+\mathrm{amb}$ ) during 5 replicate 10 d runs from May to July 1994. Ambient DIN concentrations during the experiment were $0.26 \pm 0.13 \mu \mathrm{M}$ ammonium and $0.30 \pm 0.15 \mu \mathrm{M}$ nitrate + nitrite (means \pm 1 standard deviation, $\mathrm{n}=7$ ).

Although elevated DON levels have been measured in Kane'ohe Bay (Smith et al. 1981, present study), the composition of DON has not been determined. Urea concentrations used in this experiment are within the range of DON concentrations measured in the water column near Kane'ohe Bay reef slopes (Table 1). Urea was used as an organic nitrogen source because the small, neutral urea molecule is likely to be the DON source most readily assimilated (Antia et al. 1991), and because enhanced growth following urea addition has been reported for some macroalgae (Mohsen et al.

Table 1 Mean nutrient concentrations in naturally occurnng Dictyosphaeria cavernosa chambers and in the adjacent water column. Water samples were collected from July 1993 to July 1995. Concentrations are in $\mu$ M, 1 slandard deviation in parentheses. DON: dissolved organic nitrogen; DOP: dissolved organic phosphorus

\begin{tabular}{|lccccc|}
\hline & $\mathrm{NH}_{4}$ & $\mathrm{NO}_{3}+\mathrm{NO}_{2}$ & $\mathrm{PO}_{4}$ & DON & DOP \\
\hline Dictyosphaeria cavernosa chambers & 0.47 & 1.43 & 0.18 & 7.41 & 0.23 \\
Water column & $(0.24)$ & $(0.90)$ & $(0.07)$ & $(2.40)$ & $(0.10)$ \\
$\mathrm{n}$ & 0.26 & 0.14 & 0.10 & 6.73 & 0.19 \\
& $(0.14)$ & $(0.11)$ & $(0.05)$ & $(1.58)$ & $(0.08)$ \\
\end{tabular}


1974, DeBoer et al. 1978, Probyn \& Chapman 1982). Ammonium concentrations $\geq 1 \mu \mathrm{M}$ have been shown to suppress urea uptake in phytoplankton, and in some cases ammonium uptake is suppressed by the addition of urea (Antia et al. 1991). These observations suggest that individual effects of urea and ammonium enrichment on $D$. cavernosa growth may be inhibited when both nutrients are provided. The factorial design of this experiment tested for such interactions

Tissue nitrogen concentrations under field conditions. On 2 dates, additional thalli were collected from the same field sites as the experimental thalli, and were washed and frozen within 1 h of collection. These thalli were prepared and analyzed for tissue nitrogen and carbon following the same procedure used for experimental thalli.

Field experiment. To compare in situ growth rates of Dictyosphaeria cavernosa thalli exposed to and isolated from sediment-derived nutrients, a field experiment was conducted on a subtidal patch reef flat $1 \mathrm{~km}$ southeast of Moku o Lo'e. D. cavernosa chambers, created when thalli overgrow the reef-building corals Porites compressa Dana and Montipora verrucosa Lamarck, are common on this reef, as are exposed sediment patches. Water depth at the study site is 3.0 to $4.5 \mathrm{~m}$.

Experimental Dictyosphaeria cavernosa thalli were prepared by coring $10 \mathrm{~cm}$ diameter, 4 to $5 \mathrm{~cm}$ thick circular disks out of larger thalli collected at the study site. Experimental thalli were cleaned of invertebrates, trimmed to 90 to $130 \mathrm{~g}$ fresh weight, and kept in a shaded tank with flowing $100 \mu \mathrm{m}$-filtered seawater overnight. Thalli were then weighed and inserted into the tops of $10 \mathrm{~cm}$ diameter, $10 \mathrm{~cm}$ tall PVC cylinders to form experimental chambers, with approximately $1 \mathrm{~cm}$ of thallus protruding from the top of each cylinder. Half of the chambers functioned as controls, and had tightfitting plastic bottoms to prevent sediment-derived nutrients from reaching the undersides of the thalli. The other chambers had no bottoms and the undersides of the thalli were exposed to $78.5 \mathrm{~cm}^{2}$ areas of sediment. Control and treatment chambers were randomly paired and installed about $1 \mathrm{~m}$ apart on individual sediment patches. The chambers were pressed about $2 \mathrm{~cm}$ into sediment and were weighted to keep them upright. The bottom of each thallus was approximately $5 \mathrm{~cm}$ above the sediment surface. These small thalli and chambers were meant to simulate the growth habits of naturally occurring $D$. cavernosa. After 12 to $15 \mathrm{~d}$, the chambers were recovered and the experimental thalli were reweighed and specific growth rates calculated. A total of 16 pairs of control and treatment thalli were used during 3 runs of the experiment, carried out in October and November 1994.
Nutrient availability in treatment and control chambers and in the overlying water column was measured on 2 dates during the field experiment. Water samples were collected from within and $1 \mathrm{~m}$ adjacent to chambers, at the same depth. Samples from experimental chambers were collected by inserting a $15 \mathrm{~cm}$ Pasteur pipette attached to a $150 \mathrm{ml}$ syringe through small holes in the thalli and withdrawing $100 \mathrm{ml}$ of seawater from each chamber

Data analyses. For laboratory experiments using growth rates as dependent variables, the last set of growth increments calculated for each experimental treatment were used in analyses to minimize the effects of acclimation and initial responses to treatments on later growth rates. Plots of growth rate vs elapsed time were used to confirm that growth rates were fairly stable at the conclusion of experimental runs. Growth rates of the 3 thalli in each culture container were averaged and treated as a single data point.

To examine relationships between external nitrogen concentration, specific growth rate and tissue nitrogen level, the data from Expts 1 and 2 were analyzed using least squares linear regressions. Growth rates and $\mathrm{N}: \mathrm{C}$ atomic ratios in Expt 2 increased logarithmically with nitrogen concentration, and regressions were calculated using log-transformed nitrogen concentrations The inverse prediction procedure (Sokal \& Rohlf 1981) was used with the regression models resulting from Expts 1 and 2 to estimate the subsistence DIN concentration and the subsistence tissue nitrogen level (the external DIN and tissue nitrogen concentrations, respectively, at which growth can just be sustained) The tissue nitrogen concentrations used in the growth vs tissue nitrogen regression were random, i.e. not predetermined, which violates the assumptions of least squares regression analysis, so the subsistence tissue nitrogen level was also predicted using a geometric mean regression (Sokal \& Rohlf 1981) for comparison. Factorial ANOVAs were used to compare differences among experimental treatments in Expts 3 and 4. Specific growth rates of control and treatment thalli from the field experiment were compared using a 1-way ANOVA. When replicate experimental runs were carried out, runs were treated as blocks. When water samples were collected in pairs, e.g. from within and adjacent to Dictyosphaeria cavernosa chambers, and from treatment and control chambers in the field experiment, nutrient concentrations were compared using pairs as blocks. The nutrient data from water samples collected near the Moku o Lo'e reef slope were analyzed with mean square successive difference tests (Zar 1984). This test was used to determine whether successive nutrient measurements in the dataset were correlated, i.e. whether there was a non-random pattern in the temporal sequence. 


\section{RESULTS}

\section{Field nutrient concentrations and flow rates}

DIN concentrations in the water column near the Moku o Lo'e reef slope were generally less then $0.5 \mu \mathrm{M}$. The mean nitrate+nitrite concentration was higher than the mean ammonium concentration (means \pm 1 standard deviation: nitrate+nitrite $0.25 \pm 0.34 \mu \mathrm{M}$, ammonium $0.14 \pm 0.12 \mu \mathrm{M}$ ) but this was not consistently the case (Fig. 1). The mean ( \pm 1 standard deviation) phosphate concentration was $0.11 \pm 0.01 \mu \mathrm{M}$ (Fig. 1). There was no seasonal pattern in the water column nutrient data, and successive measurements were not correlated for ammonium, nitrate+nitrite or phosphate (mean square successive difference tests, $p>0.05$ ).

Ammonium concentrations were consistently higher in the ambient seawater used in laboratory experiments (mean \pm 1 standard deviation: $0.50 \pm 0.31 \mu \mathrm{M}$ ) than in the Moku o Lo'e water column, even though the water column samples were collected within $1 \mathrm{~m}$ of the intake pipe for the laboratory seawater system. This difference $(0.36 \mu \mathrm{M})$ is significant ( $p<0.001$ ), based on a set of 23 paired samples collected near the intake pipe and from the laboratory seawater system. Differences between nitrate+nitrite and phosphate concentrations in samples from the laboratory seawater system and the water column were not significant $(p>0.05)$. Ammonium enrichment in the seawater system is probably due to the presence of ammoniotelic invertebrates in the pipes and headboxes of the seawater system.

Ammonium concentrations within naturally occurring Dictyosphaeria cavernosa chambers were nearly twice as high. and nitrate+nitrite concentrations 10 times higher, than in the water column adjacent to the chambers (Table 1). For both nutrients, the difference between chamber and water column concentration was significant (paired sample t-tests, $p<$ 0.001). The difference between phosphate concentrations in chamber and water column samples was not significant $(p>0.05)$. A subset of the paired chamber and water column samples were analyzed for total dissolved nitrogen and total dissolved phosphorus, and dissolved organic nitrogen and phosphorus concentrations were calculated from these measurements (Table 1). Differences between dissolved organic nitrogen and phosphorus concentrations in $D$. cavernosa chambers and the adjacent water column were not significant (paired sample t-tests, $\mathrm{p}>0.05$ ).

Relative flow rates were measured at several sites on the Moku o Lo'e reef slope (2 to $3 \mathrm{~m}$ depth) and reef flat $(0.5$ to $1 \mathrm{~m}$ depth). These sites all had high Dictyosphaeria cavernosa cover. Flow rates at the surface of $D$. cavernosa thalli ranged from $0.8 \mathrm{~cm} \mathrm{~s}^{1}$ on the leeward reef slope to $6.0 \mathrm{~cm} \mathrm{~s}^{-1}$ on the windward reef flat (Table 2). Flow rates within naturally occuring $D$. cavernosa chambers on the windward side of Moku o Lo'e were 60 to $70 \%$ of those measured on the outer surfaces of the same thalli; on the leeward reef slope, flow rates within chambers were very similar to those on the outer surfaces (Table 2)

\section{Expt 1: Subsistence DIN level}

Growth rates of Dictyosphaeria cavernosa thalli increased linearly with ammonium enrichment, confirming that $D$. cavernosa is limited by inorganic nitro-
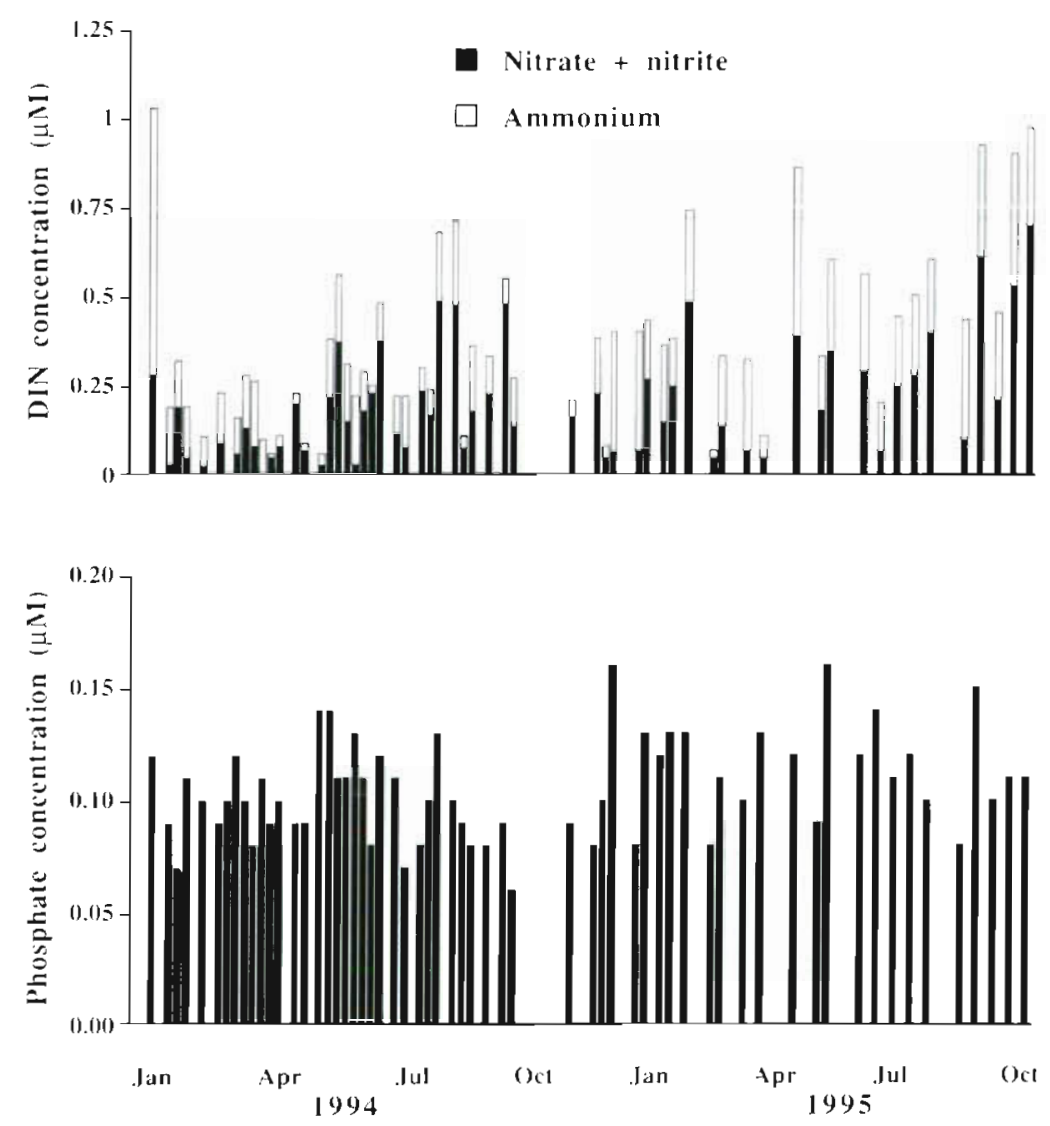

Fig. 1 Inorganic nitrogen and phosphate concentrations in the water column $2 \mathrm{~m}$ from the windward Moku o Lo'e reef slope (Hawai'i, USA), at 2 to $3 \mathrm{~m}$ depth. Samples were collected 2 to 4 times a month at a point near the Hawai' 1 Institute of Marine Biology seawater system intake pipe 
Table 2. Mean relative seawater flow rates across the surfaces of Dictyosphaena cavernosa thalli and withın naturally occurring $D$. cavernosa chambers on the windward and leeward sides of Moku o Lo'e. Flow rates are in $\mathrm{cm} \mathrm{s}^{-1}$, standard deviation in parentheses. NM: no measurement

\begin{tabular}{|c|c|c|c|c|c|c|}
\hline \multirow[t]{2}{*}{ Date } & \multicolumn{2}{|c|}{ Windward reef flat } & \multicolumn{2}{|c|}{ Windward recf slope } & \multicolumn{2}{|c|}{ Leeward reef slope } \\
\hline & Surface & Chamber & Surface & Chamber & Surface & Chamber \\
\hline 29 Jul 1995 & $\begin{array}{c}4.41 \\
(0.94) \\
\mathrm{n}=10\end{array}$ & $\begin{array}{c}2.72 \\
(0.85) \\
\mathrm{n}=10\end{array}$ & $\begin{array}{c}1.29 \\
(0.29) \\
\mathrm{n}=11\end{array}$ & $\begin{array}{c}0.90 \\
(0.35) \\
n=11\end{array}$ & $\begin{array}{c}0.85 \\
(0.26) \\
n=10\end{array}$ & $\begin{array}{c}0.78 \\
(0.10) \\
n=10\end{array}$ \\
\hline 28 Dec 1995 & $\begin{array}{c}5.99 \\
(0.43) \\
n=10\end{array}$ & $\begin{array}{c}3.56 \\
(1.02) \\
n=10\end{array}$ & $\begin{array}{c}1.44 \\
(0.10) \\
\mathrm{n}=10\end{array}$ & $\begin{array}{c}0.87 \\
(0.12) \\
n=10\end{array}$ & $\begin{array}{c}0.83 \\
(0.31) \\
\mathrm{n}=10\end{array}$ & $\begin{array}{c}0.92 \\
(0.25\} \\
n=10\end{array}$ \\
\hline 2 Mar 1996 & $\begin{array}{c}3.94 \\
(0.30) \\
n=11\end{array}$ & NM & $\begin{array}{c}0.99 \\
\{0.15\} \\
n=11\end{array}$ & $N M$ & NM & NM \\
\hline 21 Mar 1996 & $\begin{array}{c}4.07 \\
(0.74) \\
n=11\end{array}$ & NM & $\begin{array}{c}3.56 \\
(1.06) \\
n=11\end{array}$ & NM & NM & NM \\
\hline
\end{tabular}

gen availability at the laboratory flow rate of $9.5 \mathrm{~cm} \mathrm{~s}^{-1}$ (Fig. 2, Table 3). The regression equation was: specific growth rate $=0.04(\mathrm{DIN})-0.03, \mathrm{R}^{2}=0.34, \mathrm{p}<0.005, \mathrm{n}=$ 30 . The subsistence DIN concentration $( \pm 95 \%$ confidence interval) estimated from the regression equation was $0.73 \pm 0.51 \mu \mathrm{M}$.

Tissue $\mathrm{N}: \mathrm{C}$ ratios in Expt 1 appeared to increase slightly with increasing external nitrogen concentration, with mean values ranging from 0.039 in thalli from the ambient treatment to 0.047 in thalli from the $0.5 \mu \mathrm{M}$ ammonium enrichment treatment. This trend was not significant; the least squares linear regression did not explain a significant amount of the variability in N:C ratios and the slope of the regression line was not significantly different from zero.

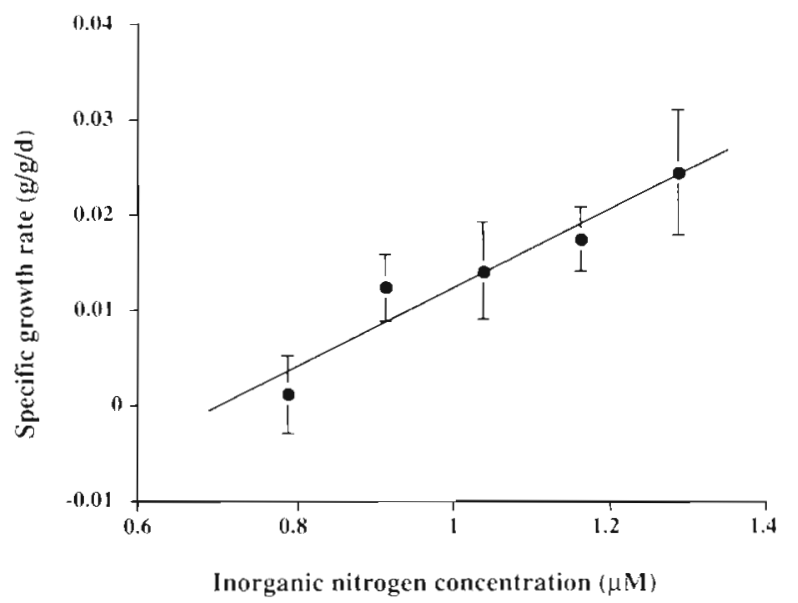

Fig. 2. Expt 1. Mean specific growth rates of Dictyosphaeria cavernosa thalli in the subsistence DIN experiment. Error bars are 1 standard error, $\mathrm{n}=6$. Line corresponds to the least squares linear regression equation

\section{Expt 2: Saturating DIN level}

As in Expt 1, ammonium enrichment enhanced the growth of Dictyosphaeria Cavernosa thalli. At the laboratory flow rate of $9.5 \mathrm{~cm} \mathrm{~s}^{-1}$, growth rates reached a maximum at a DIN concentration of approximately $17 \mu \mathrm{M}(0.5 \mu \mathrm{M}$ ambient ammonium + $0.5 \mu \mathrm{M}$ ambient nitrate $+16 \mu \mathrm{M}$ added ammonium), and then declined (Fig. 3A). The mean growth rate in the $17 \mu \mathrm{M}$ treatment was $0.04 \mathrm{~g} \mathrm{~g}^{-1} \mathrm{~d}^{-1}$, which is equivalent to a biomass doubling time of $18 \mathrm{~d}$. Reduced growth rates at ammonium enrichment levels above $20 \mu \mathrm{M}$ may have been due to ammonium toxicity. Growth or photosynthetic rate inhibition due to ammonium toxicity have been demonstrated in several macroalgal species at ammonium levels between 25 and $40 \mu \mathrm{M}$ (Waite \& Mitchell 1972, Haines \& Wheeler 1978, Kautsky 1982). Although mathematical approaches are available for describing data which show such a hyperbolic curve, e.g. photosynthesis vs irradiance curves with photoinhibition (Platt et al. 1980), there were insufficient

Table 3. Expt 1 (subsistence DIN, dissolved inorganic nitrogen). Specific growth of Dictyosphaeria cavernosa thalli Least squares regression table and significance tests for slope and intercept

\begin{tabular}{|lrccc|}
\hline Source & df & MS & $F$ & $\mathrm{p}$ \\
\hline Regression & 1 & $1.59 \times 10^{-3}$ & 14.36 & $<0.005$ \\
Error & 28 & $1.11 \times 10^{-4}$ & & \\
Total & 29 & & & \\
Parameter & Coefficient & SD & $t$ & $\mathrm{p}$ \\
\hline $\begin{array}{l}\text { Intercept } \\
\text { Slope }\end{array}$ & -0.030 & 0.012 & -2.55 & $<0.05$ \\
& 0.041 & 0.010 & 3.79 & $<0.05$ \\
\hline
\end{tabular}



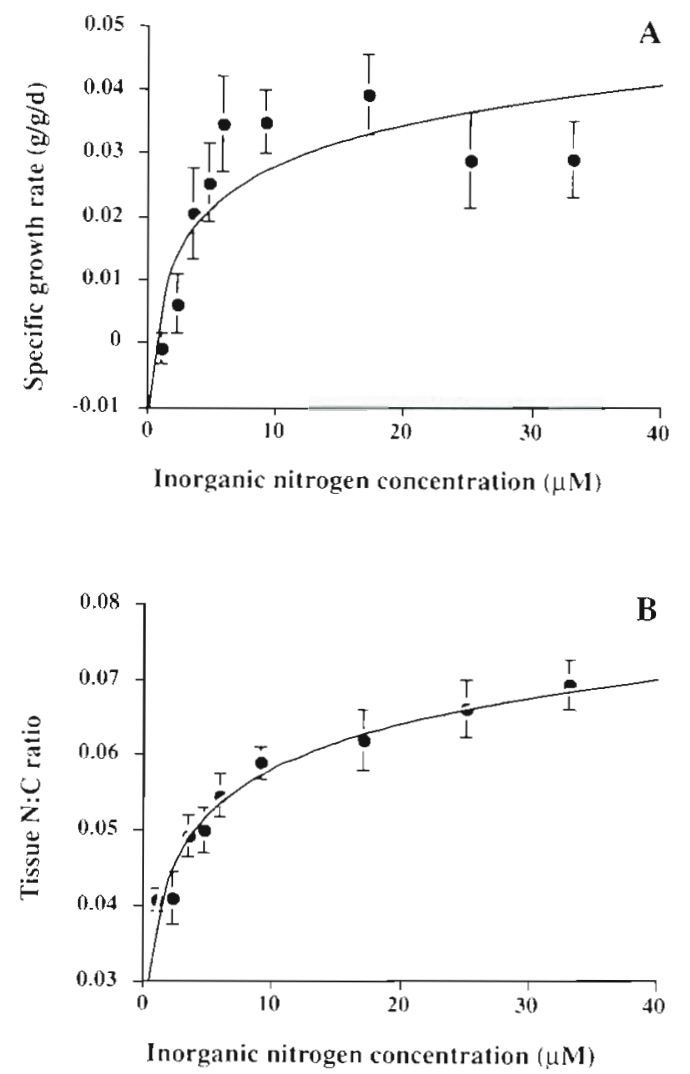

Fig. 3. Expt 2. (A) Mean specific growth rates of Dictyosphaeria cavernosa thall in the saturating DIN expertment. Error bars are 1 standard error, $\mathrm{n}=6$. Line corresponds to least squares linear regression equation using log-transformed DIN concentrations. (B) Mean tissue N:C atomic ratios of $D$. Cavernosa thalli in Expt 2. Error bars are 1 standard error, $\mathrm{n}=4$. Line corresponds to least squares linear regression equation using log-transformed DIN concentrations

data at high DIN concentrations to fit such a curve. Other nutrient saturation functions fitted to the entire range of data in Fig. 3A were strongly influenced by the 2 right hand points, thus reducing the goodness-of-

Table 4A. Expt 2 (saturating DIN). Specific growth of Dictyosphaeria cavernosa thalli. Least squares regression table and significance tests for slope and intercept

\begin{tabular}{|lrccc|}
\hline Source & df & MS & $F$ & $p$ \\
\hline Regression & 1 & $5.56 \times 10^{-3}$ & 21.95 & $<0.001$ \\
Error & 52 & $2.53 \times 10^{-1}$ & & \\
Total & 53 & & & \\
Parameter & Coefficient & SD & $t$ & $p$ \\
\hline Intercept & 0.006 & 0.004 & 1.39 & $>0.1$ \\
Slope & 0.009 & 0.002 & 4.69 & $<0.001$ \\
\hline
\end{tabular}

fit at low DIN concentrations. Since growth inhibition at high DIN concentrations was not of primary interest. the 2 right hand points were excluded from the analysis; for the remaining data, thallus growth rates increased with the $\log$ of the DIN concentration The regression equation was: specific growth rate = $0.017 \ln (\mathrm{DIN})-0.018, \mathrm{R}^{2}=0.51, \mathrm{p}<0.001, \mathrm{n}=42$ (Table $4 \mathrm{~A}$ ). The subsistence DIN concentration $( \pm 95 \%$ confidence interval) estimated from the regression equation was $1.11 \pm 0.34 \mu \mathrm{M}$. This confidence interval overlaps the confidence interval around the subsistence concentration from Expt 1.

Tissue N:C ratios increased with the log of the DIN concentration (Fig 3B, Table 4B). The regression equation was: $\mathrm{N}: \mathrm{C}=0.009 \ln (\mathrm{DIN})+0.038, \mathrm{R}^{2}=0.81$, $p<0.001, n=28$. Mean tissue $\mathrm{N}: \mathrm{C}$ ratios ranged from 0.04 in the ambient and $1.2 \mu \mathrm{M}$ enrichment treatments, to 0.07 in the $32 \mu \mathrm{M}$ enrichment treatment.

The subsistence tissue nitrogen level for Dictyosphaeria cavernosa was estimated by regressing growth rate on tissue nitrogen concentration (Fig. 4), and using the inverse prediction procedure to predict the tissue nitrogen concentration at which the growth rate was zero. As in previous analyses, the 2 points corresponding to inhibited growth at high ammonium concentrations were not included in the regression, although they are shown in Fig. 4. The regression equation was: specific growth rate $=0.007$ (tissue nitrogenj-0.039, $\mathrm{R}^{2}=0.39, \mathrm{p}<0.005, \mathrm{n}=22$. The predicted subsistence tissue nitrogen level $( \pm 95 \%$ confidence interval) was $5.57 \pm 2.58 \mathrm{mg}$ nitrogen ( $g$ dry tissue $)^{-1}$. The geometric mean regression equation for the same data was: specific growth rate $=0.012$ (tissue nitrogen) - 0.0504, and the predicted subsistence tissue nitrogen level was 4.31 , which lies within the $95 \%$ confidence interval calculated for the least squares regression. Because growth rates did not approach an asymptote with increasing DIN concentration (Fig. 3A), the critical tissue nitrogen level could not be estimated reliably.

Table 4B. Expt 2 (saturating DIN). Dictyosphaena cavernosa thallus $\mathrm{N}: \mathrm{C}$ ratios. Least squares regression table and significance tests for slope and intercept

\begin{tabular}{|lrccc|}
\hline Source & $\mathrm{d} f$ & $\mathrm{MS}$ & $F$ & $\mathrm{p}$ \\
\hline Regression & 1 & $2.69 \times 1.0^{-3}$ & 113.47 & $<0.001$ \\
Error & 26 & $2.37 \times 10^{-5}$ & & \\
Total & 27 & & & \\
Parameter & Coefficient & $\mathrm{SD}$ & $t$ & $\mathrm{p}$ \\
\hline Intercept & 0.038 & 0.002 & 21.24 & $<0.001$ \\
Slope & 0.009 & 0.001 & 10.65 & $<0.001$ \\
\hline
\end{tabular}




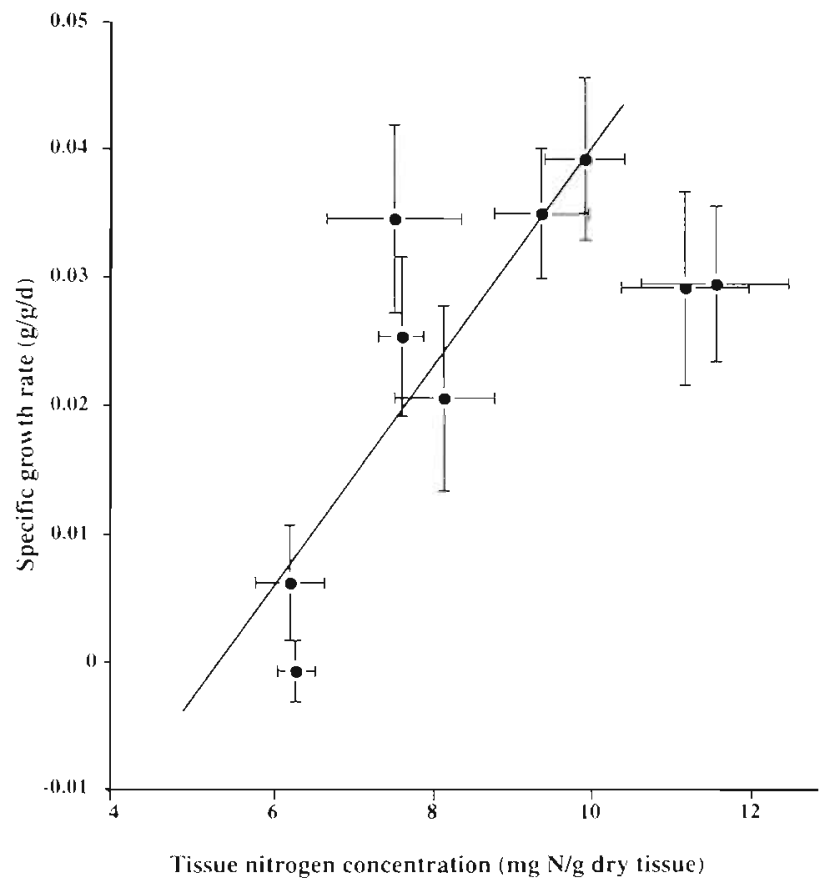

Fig. 4. Expt 2. Mean specific growth rate of Dictyosphaeria cavernosa thalli versus tissue nitrogen concentration in the saturating DIN experiment. Error bars in both directions are 1 standard error, $n=4$. Line corresponds to the least squares linear regression

\section{Expt 3: Ammonium- vs nitrate-enhanced growth}

Dictyosphaeria cavernosa thalli which were grown in either ammonium- or nitrate-enriched seawater grew at significantly higher rates than thalli grown in unenriched seawater (Fig. 5, Table 5). There was no ammonium-by-nitrate interaction, indicating that assimilation of one nutrient was not inhibited or enhanced by the other. Growth rates of thalli in both the 0.5 and $2 \mu \mathrm{M}$ ammonium enrichment treatments were significantly higher than in the ambient treatment, and growth in the $2 \mu \mathrm{M}$ ammonium treatment was significantly higher than in the $2 \mu \mathrm{M}$ nitrate treatment (Tukey tests, $\mathrm{p}<$ 0.001 for $2 \mu \mathrm{M}$ ammonium vs ambient, $\mathrm{p}<$ 0.01 for $0.5 \mu \mathrm{M}$ ammonium vs ambient, $\mathrm{p}<$ 0.05 for $2 \mu \mathrm{M}$ ammonium vs $2 \mu \mathrm{M}$ nitrate); growth rates in the $2 \mu \mathrm{M}$ and $0.5 \mu \mathrm{M}$ ammonium enrichment treatments were not significantly different, nor were the growth rates in the $0.5 \mu \mathrm{M}$ ammonium and $0.5 \mu \mathrm{M}$ nitrate treatments. Growth in the $2 \mu \mathrm{M}$ nitrate enrichment treatment was significantly higher than in the ambient treatment (Tukey test, p $<0.05$ ), but growth in the $0.5 \mu \mathrm{M}$ nitrate treatment was not significantly different than in the ambient treatment.

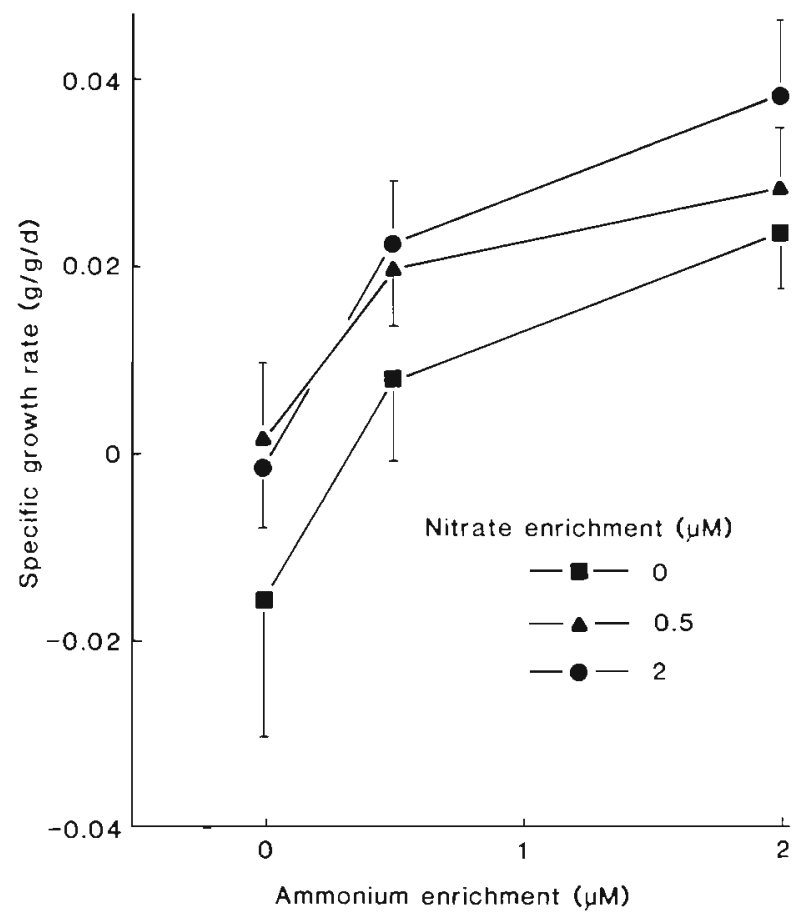

Fig. 5. Expt 3. Mean specific growth rates of Dictyosphaeria cavernosa thalli in the ammonium vs nitrate enrichment experiment. Error bars are 1 standard error, $\mathrm{n}=5$

\section{Expt 4: Ammonium-vs urea-enhanced growth}

Dictyosphaeria cavernosa thalli grown in ammonium-enriched seawater grew at significantly higher rates than thalli grown in either urea-enriched or unenriched seawater (Fig. 6, Table 6). Urea enrichment did not significantly effect growth, and there was no ammonium-by-urea interaction. Growth rates of thalli in the $2 \mu \mathrm{M}$ and $1 \mu \mathrm{M}$ ammonium enrichment treatments were significantly higher than in treatments with no ammonium enrichment (Tukey test, p < 0.001 for $2 \mu \mathrm{M}$ vs ambient, $0.01<\mathrm{p}<0.025$ for $1 \mu \mathrm{M}$ v ambient); growth rates in the $2 \mu \mathrm{M}$ and $1 \mu \mathrm{M}$ ammo-

Table 5. Expt 3 (ammonium vs nitrate enrichment). Factorial ANOVA of specific growth rates of Dictyosphaeria cavernosa. Blocks are replicate experimental runs, carried out from January 1994 to April 1995

\begin{tabular}{|lrccrl|}
\hline Source & dr & SS & MS & $F$ & p \\
\hline $\mathrm{NH}_{4}$ & 2 & $9.43 \times 10^{-3}$ & $4.72 \times 10^{-3}$ & 22.18 & $<0.001$ \\
$\mathrm{NO}_{3}$ & 2 & $1.73 \times 10^{-3}$ & $8.63 \times 10^{-4}$ & 4.06 & $<0.05$ \\
$\mathrm{NH}_{4} \times \mathrm{NO}_{3}$ & 4 & $2.63 \times 10^{-4}$ & $6.57 \times 10^{-3}$ & 0.31 & $>0.10$ \\
Blocks & 4 & $5.73 \times 10^{-3}$ & $1.43 \times 10^{-3}$ & 6.73 & $<0.001$ \\
Error & 32 & $6.80 \times 10^{-3}$ & $2.13 \times 10^{-4}$ & & \\
Total & 44 & $2.39 \times 10^{-2}$ & & & \\
\hline
\end{tabular}


Table 6. Expt 4 (ammonium vs urea enrichment). Factorial ANOVA of specific growth rates of Dictyosphaeria cavernosa. Blocks are replicate experimental runs, carried out from May to July 1994

\begin{tabular}{|lrccrc|}
\hline Source & df & SS & MS & $F$ & $p$ \\
\hline $\mathrm{NH}_{4}$ & 2 & $5.49 \times 10^{-3}$ & $2.74 \times 10^{-3}$ & 16.81 & $<0.001$ \\
Urea $_{\mathrm{NH}_{4} \times \text { Urea }}$ & 2 & $3.29 \times 10^{-4}$ & $1.64 \times 10^{-4}$ & 1.01 & $>0.10$ \\
Blocks & 4 & $4.10 \times 10^{-4}$ & $1.03 \times 10^{-4}$ & 0.63 & $>0.10$ \\
Error & 4 & $9.41 \times 10^{-4}$ & $2.35 \times 10^{-4}$ & 1.44 & $>0.10$ \\
Total & 32 & $5.23 \times 10^{-3}$ & $1.63 \times 10^{-4}$ & & \\
\hline
\end{tabular}

Table 7. Field experiment. One-way ANOVA of specific growth rates of Dictyosphaeria cavernosa. Blocks are replicate experimental runs, carried out in October and November 1994

\begin{tabular}{|lrcccc|}
\hline Sources & df & SS & MS & $F$ & $p$ \\
\hline Treatments & 1 & $3.59 \times 10^{-4}$ & $3.59 \times 10^{-4}$ & 5.07 & $<0.05$ \\
Pairs & 7 & $3.07 \times 10^{-4}$ & $4.42 \times 10^{-5}$ & 0.62 & $>0.5$ \\
Blocks & 2 & $2.66 \times 10^{-4}$ & $1.33 \times 10^{-4}$ & 1.88 & $>0.5$ \\
Error & 25 & $1.77 \times 10^{-3}$ & $7.08 \times 10^{-5}$ & & \\
Total & 35 & $2.70 \times 10^{-3}$ & & & \\
\hline
\end{tabular}

nium enrichment treatments were not significantly different. Urea solutions were not axenic, and may have been slightly DIN-enriched due to bacterial catabolism of urea, but ammonium and nitrate concentrations were not significantly different in 7 sets of paired water samples taken from urea and ambient seawater treatments during the experiment. The fact that there was no main effect of urea on growth indicates that urea did not directly enhance growth, and that indirect effects of ammonium produced by urea catabolism were undetectable.

\section{Field experiment}

Dictyosphaeria cavernosa thalli exposed to sediment patches for 12 to $15 \mathrm{~d}$ showed sustained growth, while control thalli lost weight (mean growth rates \pm 1 standard deviation: $3.38 \times 10^{-3} \pm 3.40 \times$ $10^{-3} \mathrm{~g} \mathrm{~g}^{-1} \mathrm{~d}^{-1}$ for sediment-exposed thalli, $-2.94 \times 10^{-3} \pm 1.12 \times 10^{-3} \mathrm{~g} \mathrm{~g}^{-1} \mathrm{~d}^{-1}$ for con-

trol thalli); the difference between these rates was significant (Table 7). The effect of pairing treatment and control chambers spatially was not significant,

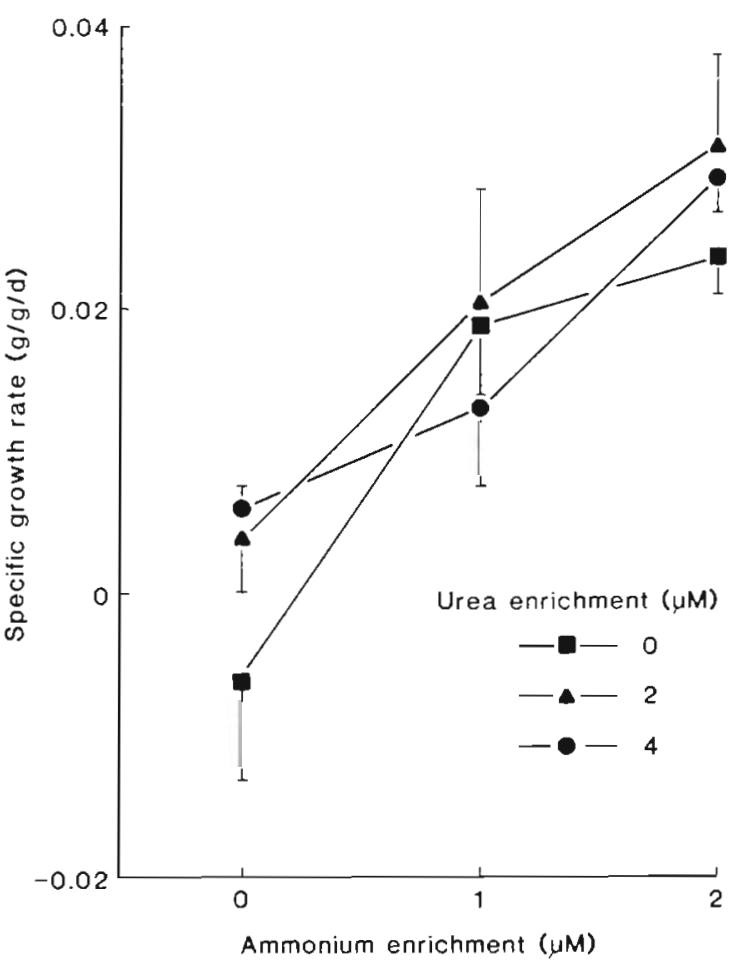

Fig. 6. Expt 4. Mean specific growth rates of Dictyosphaeria cavernosa thalli in the ammonum vs. urea enrichment experiment. Error bars are 1 standard error, $n=5$ indicating that the enhancement effect of sediment exposure on thallus growth was homogeneous at the scale of meters on this patch reef. Ammonium concentrations in water samples collected from paired treatment and control chambers were higher than ammonium concentrations in the water column (Table 8), but differences in ammonium and nitrate+nitrite concentrations in treatment and control chambers were not significant (paired t-tests, $\mathrm{p}>0.1$ for both nutrients). The mean flow rate ( \pm 1 standard deviation) at the field experiment site, measured at the surfaces of Iarge $D$. Cavernosa thalli, was $1.77 \mathrm{~cm} \mathrm{~s}^{-1} \pm 0.81$ $(n=23)$.

Table 8. Mean ammonium and nitrate+nitrite concentrations in field experiment treatment and control chambers and in the adjacent water column. Concentrations in $\mu \mathrm{M}, 1$ standard deviation in parentheses

\begin{tabular}{|lcc|}
\hline & $\mathrm{NH}_{4}$ & $\mathrm{NO}_{3}+\mathrm{NO}_{2}$ \\
\hline Treatment & 0.34 & 0.16 \\
$(\mathrm{n}=10)$ & $(0.22)$ & $(0.13)$ \\
Control & 0.35 & 0.21 \\
$(\mathrm{n}=10)$ & $(0.14)$ & $(0.20)$ \\
Adjacent water column & 0.12 & 0.15 \\
$(\mathrm{n}=5)$ & $(0.07)$ & $(0.10)$ \\
\hline
\end{tabular}




\section{DISCUSSION}

\section{Nitrogen-limited growth in Dictyosphaeria cavernosa}

Results from the laboratory experiments indicate that Dictyosphaeria cavernosa cannot sustain growth over 9 to $15 \mathrm{~d}$ periods when grown in ambient seawater from the Kane'ohe Bay water column at a flow rate of approximately $9.5 \mathrm{~cm} \mathrm{~s}^{-1}$ This flow rate is higher than rates measured at sites in Kane'ohe Bay where D. cavernosa is abundant. These results are consistent with those of Stimson et al. (1996), and confirm that D. cavernosa growth is limited by the availability of inorganic nitrogen in Kane'ohe Bay seawater. The subsistence DIN concentration predicted from the results of the laboratory experiments is approximately $1 \mu \mathrm{M}$ lestimates of $0.73 \mu \mathrm{M}$ in Expt 1 and $1.1 \mu \mathrm{M}$ in Expt 2). Since the water column DIN concentration is usually less than $0.5 \mu \mathrm{M}$, and the flow rate in the field is generally less than that used in the laboratory experiments (Table 2), the DIN subsidy (DIN in addition to water column DIN) needed for sustained growth in the field is in excess of $0.5 \mu \mathrm{M}$. DIN in the water column is composed of both ammonium and nitrate+nitrite, however, and since nitrate is less effective in enhancing $D$. cavernosa growth than ammonium (see 'Results', Expt 3), the actual DIN subsidy required is probably even higher. DIN concentrations within naturally occurring $D$. cavernosa chambers appear to meet this requirement (Table 1).

Results of the field experiment indicate that net growth of Dictyosphaeria cavernosa in the field is made possible by the availability of DIN in the water below thalli. Only thalli which were exposed to sediments sustained growth in this experiment. Control thalli, which were exposed to the same DIN flux from the water column, but were isolated from sediments, did not grow. DIN enrichment in the water between sediments and $D$. cavernosa thalli is presumably due to efflux from sediments; mixing and dilution of sediment-derived DIN into the overlying water column is slowed by the algal thallus. Net efflux of DIN from Kane'ohe Bay reef sediments has been measured with benthic chambers (author's unpubl. data) and DIN concentrations within naturally occuring $D$. Cavernosa chambers are significantly higher than in the adjacent water column (Table 1). This supports the hypothesis that sediment efflux provides DIN to overlying $D$. cavernosa thalli.

\section{Effects of ammonium, nitrate and urea enrichment on Dictyosphaeria cavernosa growth}

Seawater enriched with either ammonium or nitrate resulted in enhanced growth in Dictyosphaeria cavernosa thalli (Fig. 4). Nitrate enrichment was effective in the $2 \mu \mathrm{M}$ enrichment treatment, but enrichment with $0.5 \mu \mathrm{M}$ nitrate did not affect growth rates. In contrast, enrichment with $\leq 0.5 \mu \mathrm{M}$ ammonium enhanced growth in 2 experiments (Expts 1 and 3). Differences in the effects of these nutrients may be related to the different energetic requirements of ammonium and nitrate assimilation. Ammonium can be incorporated directly into amino acid synthesis without reduction, while nitrate must be reduced to nitrite and then to ammonium before assimilation; the energetic cost of nitrate assimilation may be over $20 \%$ higher than that of ammonium assimilation (Thompson et al. 1989, Levasseur et al. 1993). To date, no nitrate uptake measurements have been made with $D$. cavernosa thalli, so the question of relative uptake rates for ammonium and nitrate remains unanswered. Although nitrate concentrations exceed ammonium concentrations in $D$. cavernosa chambers, nitrate efflux from sediments underlying $D$. cavernosa thalli is slower than ammonium efflux (author's unpubl. data). This suggests that ammonium is taken up by $D$. cavernosa more rapidly than nitrate under field conditions.

DON is available to Dictyosphaeria cavernosa at concentrations 4 to 17 times higher than DIN (Table 1), but results of Expt 4 indicated that enrichment with DON in the form of urea had no effect on thallus growth (Fig. 5, Table 6). In studies using multiple nitrogen sources, urea enrichment enhanced the growth of some macroalgal species, but in most cases, urea was not the preferred nitrogen source (Mohsen et al. 1974, DeBoer et al. 1978, Probyn \& Chapman 1982). The lack of growth enhancement by urea in the present study may be due to the absence of the catalytic enzymes urease or urea amidolyase (Antia et al. 1991) in D. cavernosa, or, as with nitrate, to the energetic cost of taking up and assimilating urea.

\section{Tissue nitrogen levels and nitrogen storage}

The subsistence tissue nitrogen level was estimated to be $5.57 \pm 2.58 \mathrm{mg}$ nitrogen (g dry tissue) ${ }^{-1}$, or $0.56 \%$ by dry weight. This concentration is within the range of subsistence tissue nitrogen levels reported for other macroscopic chlorophytes: 0.3 to $2.4 \%$ dry weight (Gordon et al. 1981, Rosenberg et al. 1984, Fujita et al. 1989, Björnsäter \& Wheeler 1990). The tissue nitrogen concentration corresponding to maximum growth rate was approximately $10 \mathrm{mg}$ nitrogen (g dry tissue) ${ }^{-1}$ (Fig. 4). The tissue nitrogen level of Dictyosphaeria cavernosa thalli under field conditions ranged from 6.0 to $10.5 \mathrm{mg}$ nitrogen ( $\mathrm{g}$ dry tissue) $)^{-1}$ (mean \pm 1 standard deviation: $8.43 \pm 1.62, n=8$ ). A comparison of tissue nitrogen at maximum growth with field values (10 vs 8.43) suggests that there is not only sufficient tissue 
nitrogen in thalli for sustained growth in the field, but that field growth rates may be near maximum.

The maximum tissue nitrogen concentration measured in Expt 2 was $13.0 \mathrm{mg}$ nitrogen ( $\mathrm{g}$ dry tissue) ${ }^{-1}$, or $1.30 \%$ by dry weight. The small difference between maximum and subsistence nitrogen levels in Dictyosphaeria cavernosa $(0.74 \%)$ in comparison to other macroalge (Lobban \& Harrison 1994) suggests that when external nitrogen concentrations are at growthsaturating levels, little nitrogen is allocated to reserve pools. Results from pulsed nutrient experiments carried out by Stimson et al. (1996) support the hypothesis that nitrogen storage capacity in $D$. cavernosa is limited. When provided with $24 \mathrm{~h}$ ammonium pulses of 50 or $100 \mu \mathrm{M}, D$. cavernosa growth rates increased, and then declined to control (no ammonium pulse) levels within 2 to $4 \mathrm{~d}$. In contrast, greater storage capacity in a variety of macroalgal forms (e.g. Chaetomorpha linum. Gracilaria tikvahiae and Macrocystis pyrifera) allow these species to grow at non-nitrogen limited rates for 14 to $60 \mathrm{~d}$ under low- or no-nitrogen conditions following nitrogen pulses (Ryther et al. 1981, Fujita 1985, Zimmerman \& Kremer 1986, Lavery \& McComb 1991). The ratio of maximum to minimum tissue nitrogen concentrations has been used as an index of storage capacity (Lobban \& Harrison 1994) The maximum to minimum tissue nitrogen ratio in experimental $D$. cavernosa thalli was 2.33 , and the ratio for thalli under field conditions was 1.75. These are very low values compared to those in Lobban \& Harrison's (1994) review.

A caveat is in order regarding the use of tissue nitrogen levels to predict nitrogen storage capacity: for most macroalgae, including Dictyosphaeria cavernosa, the composition and even the existence of a nitrogen pool specifically allocated to storage has not been identified. With the exception of pools of unassimilated nitrogen, such as vacuolar nitrate (Chapman \& Craigie 1977. Hwang et al. 1987, McGlathery 1992), nitrogen. taken up by algal tissues is rapidly assimilated into biochemically active compounds, and is recycled within tissues to meet changing physiological needs (Fujita et al. 1988, Vergara et al. 1995). Thus, the use of tissue nitrogen as a measure of nitrogen storage capacity assumes that all intracellular nitrogen in excess of the critical level can be reallocated to growth processes when external nitrogen becomes limiting (Hanisak 1983).

\section{Sources of nitrogen for Dictyosphaeria cavernosa}

The water column overlying the benthos is generally considered to be the sole or primary nutrient source for benthic algae (Hanisak 1983), but several studies have shown that nutrients released from sediments beneath dense algal mats or banks provide a large fraction of the nutrient requirements of the algae (Lapointe \& O'Connell 1989, Lavery \& McComb 1991, KrauseJensen et al. 1996). Nitrogen released by the sediments beneath Dictyosphaeria cavernosa thalli appear to be essential to the sustained growth and persistence of $D$. cavernosa in Kane'ohe Bay. Direct evidence that nitrogen taken up by $D$. cavernosa or other macroalgae is derived from sediments is still lacking Such evidence will probably require comparisons of nitrogen isotope ratios in the water column, interstitial water and $D$. cavernosa tissues, or tracer experiments using radiolabeled nitrogen

The role of water motion and turbulence-enhanced nutrient supply has not been directly addressed in this study, but could have important consequences for nutrient-limited growth in Dictyosphaeria cavernosa. Although the emphasis here has been on nutrients supplied by sediments to the undersides of $D$. cavernosa thalli, flow rates across the upper surfaces of thalli are higher than across the undersides (Table 2). This raises the possibility that the rate of supply of DIN from the relatively low concentration but rapidly flowing water column to thalli may be equal to or greater than from the nitrogen-enriched but slower moving water within $D$. cavernosa chambers.

We recognize that nutrient-limited growth is regulated by rates of nutrient supply, and not by external nutrient concentrations, per se (Lobban \& Harrison 1994). Nutrient supply (or flux or loading) rates to Dictyosphaeria cavernosa thalli in field and laboratory experiments can be estimated as the products of nutrient concentration and flow rate (Lapointe \& Ryther 1979, Fujita \& Goldman 1985, Krause-Jensen et al. 1996). DIN supply rates in the field, estimated using the data in Tables 1 \& 2, ranged from 1.1 to $86 \mu \mathrm{mol}$ $\mathrm{cm}^{-2} \mathrm{~h}^{-1}$ for the surfaces of $D$. cavernosa thalli facing the water column, and from 5.3 to $24.4 \mu \mathrm{mol} \mathrm{cm} \mathrm{cm}^{-2} \mathrm{~h}^{-1}$ for the surfaces of thalli facing sediments. These estimates support the hypothesis that nutrient efflux from sediments beneath thalli is a major source of inorganic nitrogen for $D$. cavernosa. Further support comes from results of the field experiment (Table 7), which indicate that the enriched DIN concentrations in the slowmoving water beneath thalli are high enough to significantly enhance growth, and in fact make sustained growth possible.

Acknowledgements. We thank C. Fuke, J. Gomas and N. Rojek for assistance in the field and Jaboratory. M. Atkinson, R. Kinzie, C. Smith and A. Taylor reviewed earlier drafts of this paper. Seawater nutrients were analyzed by $T$ Walsh, Analytical Services, University of Hawal'i. Facilities were provided by Hawal' Institue of Marine Biology. This research was funded by the Unuversity of Hawai' seagrant College 
Program, School of Ocean and Earth Science and Engineering, Institutional Grant NA36RGO507 The views expressed herein are those of the authors and do not necessarily reflect the views of NOAA or any of its sub-agencies. UNIHI-Seagrant-JC-96-18. This is HIMB contribution 1003

\section{LITERATURE CITED}

Andrews JC, Müller HR (1983) Space-time variability of nutrients in a lagoon patch reef Limnol Oceanogr 28:215-227

Antia NJ. Harrison PJ, Oliveira L (1991) The role of dissolved organic nitrogen in phytoplankton nutrition, cell biology and ecology. Phycologia 30:1-89

Atkinson MJ, Bilger RW (1992) Effects of water velocity on phosphate uptake in coral reef flat communities. Limnol Oceanogr 37:273-279

Atkinson MJ, Kotler E, Newton P (1994) Effects of water velocity on respiration, calcification, and ammonium uptake of a Porites compressa community. Pac Sci 48:296-303

Bjönsäter BR, Wheeler PA (1990) Effect of nitrogen and phosphorus supply on growth and tissue composition of Ulva fenestrata and Enteromorpha intestinalis (Ulvales, Chlorophyta). J Phycol 26:603-611

Boucher G, Clavier J, Garrigue C (1994) Estimation of bottom ammonium affinity in the New Caledonia lagoon. Coral Reefs 13:13-19

Capone DG, Dunham SE, Horrigan SG, Duguay LE (1992) Microbial nitrogen transformations in unconsolidated coral reef sediments. Mar Ecol Prog Ser 80:75-88

Chapman ARO, Craigie JS (1977) Seasonal growth in Lamenaria longicruris: relations with dissolved inorganic nutrients and internal reserves of nitrogen. Mar Biol 40:197-205

Coles SL (1988) Limitations of reef coral development in the Arabian Gulf: temperature or algal competition? Proc 6th Int Coral Reef Symp 3:211-216

DeBoer JA, Guigli HJ, Israel TL, D'Elia CF (1978) Nutritional studies of two red algae. I. Growth rate as a function of nitrogen source and concentration. J Phycol 14:261-266

D'Elia CF, Webb KL, Porter JW (1981) Nitrate-rich groundwater inputs to Discovery Bay, Jamaica: a significant source of $N$ to local coral reefs. Bull Mar Sci 31:903-910

Entsch B, Boto KG, Sim RG, Wellington JT (1983) Phosphorus and nitrogen in coral reef sediments. Limnol Oceanogr 28: $465-476$

Fujita RM (1985) The role of nitrogen status in regulation transient ammonium uptake and nitrogen storage by macroalgae. J Exp Mar Biol Ecol 92:283-301

Fujta RM, Goldman JC (1985) Nutrient flux and the growth of the red alga Gracilana tikvahiae McLachlan (Rhodophyta). Botanica Mar 28:265-268

Fujita RM, Wheeler PA, Edwards RL (1988) Metabolıc regulation of ammonium uptake by Ulva rigida (Chlorophyta): a compartmental analysis of the rate-limiting step for uptake. J Phycol 24:560-566

Fujita RM, Wheeler PA, Edwards RL (1989) Assessment of macroalgal nitrogen limitation in a seasonal upwelling region. Mar Ecol Prog Ser 53:293-303

Gordon DM, Birch PB, McComb AJ (1981) Effects of inorganic phosphorus and nitrogen on the growth of an estuarine Cladophora in culture. Botanica Mar 24:93-106

Haines KC, Wheeler PA (1978) Ammonium and nitrate uptake by the marne macrophytes Hypnea musciformis (Rhodophyta) and Macrocystis pyrifera (Phaeophyta). J Phycol 14:319-324

Hanisak MD (1983) The nitrogen relationships of marine macroalgae. In: Carpenter EJ, Capone DG (eds) Nitrogen in the marine environment. Academic Press, New York p $699-730$

Hansen JAD, Alongi DM, Moriarty DJW, Pollard PC (1987) The dynamics of benthic microbial communites at Davies Reef, central Great Barrier Reef. Coral Reefs 6:63-70

Hwang SP, Williams SL, Brinkhuis BH (1987) Changes in dissolved nutrogen pools as related to nitrate uptake and assimilation in Graclaria tikvahiae McLachlan (Rhodophyta). Botanica Mar 30:11-19

Johnstone R, Koop K, Larkum AWD (1989) Fluxes of inorganic nitrogen between sediments and water in a coral reef lagoon. Proc Linn Soc NSW 1 10:220-227

Jokiel PL, Morrissey JI (1993) Water motion on coral reefs evaluation of the 'clod card' technique. Mar Ecol Prog Ser 93:175-181

Kautsky L (1982) Primary production and uptake kinetics of ammonium and phosphate by Enteromorpha compressa in an ammonium sulfate industry outlet area. Aquat Bot 12 $23-40$

Krause-Jensen D, McGlathery K, Rysgaard S, Chritensen PB (1996) Production within dense mats of the filamentous macroalga Chaetomorpha linum in relation to light and nutrient availability. Mar Ecol Prog Ser 134:207-216

Lapointe BE, Littler MM, Littler DS (1993) Modification of benthic community structure by natural eutrophication: the Belize barrier reef. Proc 7th Int Coral Reef Symp 1:323-334

Lapointe BE, O'Connell J (1989) Nutrient-enhanced growth of Cladophora prolifera in Harrington Sound, Bermuda: eutrophication of a confined, phosphorus-limited ecosystem. Estuar Coast Shelf Sci 28:347-360

Lapointe BE, Ryther JH (1979) The effects of nitrogen and seawater flow rate on the growth and biochemical composition of Gracilaria foliifera var. angustissima in outdoor cultures. Botanica Mar 22:529-537

Lavery PS, McComb AJ (1991) The nutritional eco-physiology of Chaetomorpha linum and Ulva rigida in Peel Inlet, Western Australia. Botanica Mar 34:251-260

Levasseur M. Thompson PA, Harrison PJ (1993) Physiological acclimation of marine phytoplankton to different nitrogen sources. J Phycol 29:587-595

Lewis JB (1987) Measurements of groundwater seepage flux onto a coral reef: spatial and temporal variations. Limnol Oceanogr 32:1165-1169

Littler MM, Littler DS, Lapointe BE (1988) A comparison of nutrient and light limited photosynthesis of psammophytic versus epilithic forms of Halimeda (Caulerpales, Halimedaceael from the Bahamas. Coral Reefs 6:219-225

Littler MM, Littler DS, Lapointe BE (1993) Modification of tropical reef community structure due to cultural eutrophication: the southwest coast of Martinique. Proc 7th Int Coral Reef Symp 1:335-343

Lobban CS, Harrison PJ (1994) Seaweed ecology and physiology. Cambridge University Press, New York

Marsh JA (1977) Terrestrial inputs of nitrogen and phosphorus on fringing reefs of Guam. Proc 5th Int Coral Reef Symp 1:331-336

McGlathery KJ (1992) Physiological controls on the distribution of the macroalga Spyridea hypnoldes: patterns along a eutrophication gradient in Bermuda. Mar Ecol Prog Ser 87:173-182

McGlathery KJ, Howarth RW, Marino R (1992) Nutrient limitation of the macroalga, Penicillus capitatus, associated with subtropical seagrass meadows in Bermuda. Estuaries 15:18-25

Meyer JL, Schultz ET (1985) Migrating haemulid fishes as a source of nutrients and organic matter on coral reefs. Limnol Oreanogr 30:146-156 
Mohsen AF, Khaleafa AF, Hashem MA, Metwalli A (1974) Effects of different nitrogen sources on growth, reproduction, amino acid, fat and sugar contents in Ulva fasciata Delile. Botanica Mar 17:218-222

Naim O (1993) Seasonal responses of a fringing reef community to eutrophication (Reunion Island, western Indian Ocean). Mar Ecol Prog Ser 99:137-151

Platt T, Gallegos CL, Harrison WG (1980) Photoinhibition of photosynthesis in natural assemblages of marine phytoplankton. J Mar Res 38:687-701

Powell GVN, Kenworthy WJ, Fourqurean JW (1989) Experimental evidence for nutrient limitation of seagrass growth in a tropical estuary with restricted circulation. Bull Mar Sci $44: 324-340$

Probyn TA, Chapman ARO (1982) Nitrogen uptake characteristics of Chordana flagelliformis (Phaeophyta) in batch mode and continuous mode experiments. Mar Biol 71 : $129-133$

Raven JA (1984) Energetics and transport in aquatic plants. Alan R Liss, New York

Rosenberg G, Probyn TA, Mann KH (1984) Nutrient uptake and growth kinetics in brown seaweeds: response to continuous and single additions of ammonium. J Exp Mar Biol Ecol 80:125-146

Ryther JH, Corwin N, DeBusk TA, Williams LD (1981) Nitrogen uptake and storage by the red alga Gracilaria tikvahiae (McLachlan, 1979). Aquaculture 26:107-115

Smith SV, Kimmerer WJ, Laws EA, Brock RE, Walsh TW (1981) Kaneohe Bay sewage diversion experiment: perspectives on ecosystem responses to nutritional perturbation. Pac Sci 35:279-402

Sokal RR, Rohlf FJ (1981) Biometry, 2nd edn. WH Freeman, San Francisco

This article was submitted to the editor
Stimson J, Larned ST, McDermitt K (1996) Seasonal growth of the coral reef macroalga Dictyosphaeria cavernosa (Forskål) Borgesen, and the effects of nutrient availability, temperature and herbivory on growth rate. J Exp Mar Biol Ecol 196:53-77

Thompson PA, Levasseur ME, Harrison PJ (1989) Light-limited growth on ammonium vs nitrate: what is the advantage for marine phytoplankton? Limnol Oceanogr 34: $1014-1024$

Thompson TL, Glenn EP (1994) Plaster standards to measure water motion. Limnol Oceanogr 39:1768-1779

Vergara JJ, Bird KT, Niell FX (1995) Nitrogen assimilation following $\mathrm{NH}_{4}{ }^{+}$pulses in the red alga Gracilariopsis lemaneiformis: effect on C metabolism. Mar Ecol Prog Ser 122: $253-263$

Waite T, Mitchell R (1972) The effect of nutrient fertilization on the benthic alga Ulva lactuca. Botanica Mar 15:151-156

Williams SL (1984) Uptake of sediment ammonium and translocation in a marine green macroalga Caulerpa cupressoides. Limnol Oceanogr 29:374-379

Williams SL, Carpenter RC (1988) Nitrogen-limited primary productivity or coral reef algal turfs: potential contribution of ammonium excreted by Diadema antillarum. Mar Ecol Prog Ser 47:145-152

Williams SL, Yarish SM, Gill IP (1985) Ammonium distributions, production, and efflux from backreef sediments, St Croix, US Virgin Islands. Mar Ecol Prog Ser 24:57-64

Zar JH (1984) Biostatistical analysis, 2nd edn. Prentice-Hall, Englewood Cliffs, $\mathrm{NJ}$

Zimmerman RC, Kremer JN (1986) In situ growth and chem1cal composition of the giant kelp. Macrocystis pyrifera: response to temporal changes in ambient nutrient availability. Mar Ecol Prog Ser 27:277-285

Manuscript first received: February 2, 1996

Revised version accepted: October 10, 1996 